\title{
Genetic Improvement in West Sumatera Landraces to get The Early Maturing Mutants by Induced Mutations
}

\author{
Hendra Alfi", Benny Warman ${ }^{\#}$, Irfan Suliansyah*, Etti Swasti ${ }^{*}$, and Sobrizal ${ }^{1}$ \\ \# Payakumbuh Agricultural Polytechnic, Jl. Raya Negara km. 7 Sarilamak 26271, Indonesia \\ E-mail: hendraalfi@yahoo.com \\ * Faculty of Agriculture, Andalas University, Padang 25163, Indonesia \\ ${ }^{1}$ PAIR-BATAN, Pasar Jumat Jakarta, Indonesia
}

\begin{abstract}
This study aims to improve local rice genetic West Sumatra to acquire properties that are superior (more early maturity) through mutation breeding. This study was conducted from April 2009 to December 2010. In 2009 screening at the stage orientation doses $M_{1}$ to obtain a dose treatment is effective in generating genetic diversity is very valuable in the selection effort. In 2010 the selection in a population of M2 to getting properties older than early maturing crops (early maturing mutant). The results showed that the treatment irradiation dose of $200 \mathrm{~Gy}$ is the dose that is effective in generating genetic diversity. At these doses have formed extensive genetic diversity for the variable character of the age and height of the plant. With the extent of genetic diversity of the resulting mutant candidates that can be selected at this stage of $M_{2}$. From the selection made at the stage of early maturing mutant $M_{2}$ candidates obtained as many as 86 candidates with the mutation frequency of $0.14 \%$, as well as short mutant (dwarf) and a semishort (semi-dwarf) were 97 mutants with mutant frequency of $0.16 \%$. Candidates mutant is a mutant candidates promoting to have better character as a result to be developed in the future
\end{abstract}

Keywords - West Sumatera Landrace; Induced Mutations; early maturity

\section{INTRODUCTION}

The use of improved varieties is a reliable technology in improving agricultural production. This technology is seen as safer and more environmentally friendly and less costly for farmers. But in generating improved varieties need to be carried out a series of breeding activities so that the expected benefits can be generated. Until now, various activities to produce rice varieties continue to be made. However, most of the improved varieties that produced less in demand by the people of West Sumatra because mismatches taste preferences. This causes people in West Sumatra are still a lot of local rice cultivars cultivated than modern varieties

Recently in West Sumatra there are more than 50 local rice (landraces) cultivars, both paddy and upland rice [5], and some of them are already known by the public and has a pretty good economic value. Generally, the character of the local rice cultivars in the old ( $\geq 120$ days). When the age of the local rice can be shortened (early maturing) would be better, in particular can increase the intensity as well as the annual crop can be more profitable for farmers.
Efforts for improvement Local rice genetic should be made to produce superior crops including early maturity. One way that can be done in the development of improved varieties is by mutation induced by gamma ray irradiation. Mutation breeding can support the resulting large genetic variability of plants that have a narrow genetic variability [20], [19], [10]. In addition, through mutation breeding can also be generated large genetic variability within a shorter time when compared with hybridization methods.

Mutation induction is one way to change the genetic done by humans in order to obtain better properties than the original plant properties [10], [26], [13]. Mutation induction has a significant contribution to the genetic improvement of plants in various parts of the world. In fact, at some point have an impact on the increase in production as well as rice [18], it is better to repair some properties just by not changing the majority of plant traits original that has been favored and relatively requires less time in the refining process strains [19], [2], [14]. The research objective is to get as a result of early maturing mutant local rice genetic improvement through mutation breeding of West Sumatra. 


\section{MATERIALS AND METHODS}

This research was conducted in the greenhouse facilities and rice experiment Polytechnic State Agriculture Payakumbuh since April 2009 to December 2010. The plant material used is Junjung varieties which is one of the local rice cultivars West Sumatra. Seed blue label irradiated with a beam of $\gamma$ with doses of $0 \mathrm{~Gy}$ (control), $100 \mathrm{~Gy}, 200 \mathrm{~Gy}, 300$ Gy, 400 Gy, 500 Gy, 600 Gy, 700 Gy, 800 Gy, 900 Gy, and 1000 Gy of 100 grams per dose as seed M1. Seed irradiation is done in PAIR-BATAN, Pasar Jumat Jakarta with $\gamma$-ray radiation source (gamma) used Co60 of Gammacell Chamber. Once irradiated, each irradiation dose of 200 seeds planted in the seedbed for three weeks to observe the effect of irradiation on the growth pattern of the seeds and determine the value of LD50. In addition, it also made observations of chlorophyll mutations according to the Gustafssons method [8], to determine the frequency of mutant and mutation frequency.

Treatment dosage is best then the garden to get the source of planting material and plant strains formation at the stage of M2. Furthermore, each strain were planted about 100 plants per planting hole. Plants grown in paddy rice cultivation as well maintained as usual. In the generative growth phase carried out observations of genetic diversity, heritability and the selection of the target mutant (mutant-old early maturing). The determination of the genetic variability was performed according to methods Khan [16], in which a character has a genetic variability that is broad if the value of genetic variance $(\sigma 2 \mathrm{~g})$ more than twice the standard deviation of genetic or expressed by the formula $\sigma 2 \mathrm{~g}>2$ $(\sigma \sigma 2 \mathrm{~g})$, reverse genetic variability narrow if $\sigma 2 \mathrm{~g}<2(\sigma \sigma 2 \mathrm{~g})$. Determination of heritability done using analysis of variance components and is calculated based on the formula proposed [29] and [6] in which the heritability estimates higher when $(\mathrm{H}>50 \%)$, moderate $(20 \% \leq \mathrm{H} \leq 50 \%)$, and low $(\mathrm{H}<20 \%)$.

\section{RESULTS AND DISCUSSION}

At this stage of the $\mathrm{M}_{1}$, from research conducted during germination until age 21 day after planted can be seen clearly seedling growth response (percentage of germination, seedling height, root length and percentage of germination) local rice cultivars West Sumatra to the irradiation dose being treated. Seedling growth response to treatment irradiation dose can be seen in Figure 1. In Figure 1a. it appears that the higher the dose of irradiation, can reduce the ability to grow crops. In fact, at doses above $500 \mathrm{~Gy}$, causing death in sprouts (lethal effects). The declining vitality of the plant due to the deterministic effects due to gamma-ray irradiation.

Deterministic effect is the effect caused by cell death due to radiation exposure. The deterministic effects occur when the dose received by the plant above the threshold dose (threshold dose) and generally arise some time after irradiation. Heightened reduction of growth due to the increasing size of the dose proves that the irradiation dose is very direct effect on physical damage (physical damage) plants. Damage to the M1 generation is due to ionizing radiation treatment [7]. In general, the physiological damage are more descriptive. It can be observed directly morphologically. Increased doses of mutagens causing mortality rate higher plants with a low mutation frequency. It is the result of damage extrachromosomal. Conversely if these mutagens cause mortality rates were low and the high frequency of mutation is believed to be due to chromosomal damage.

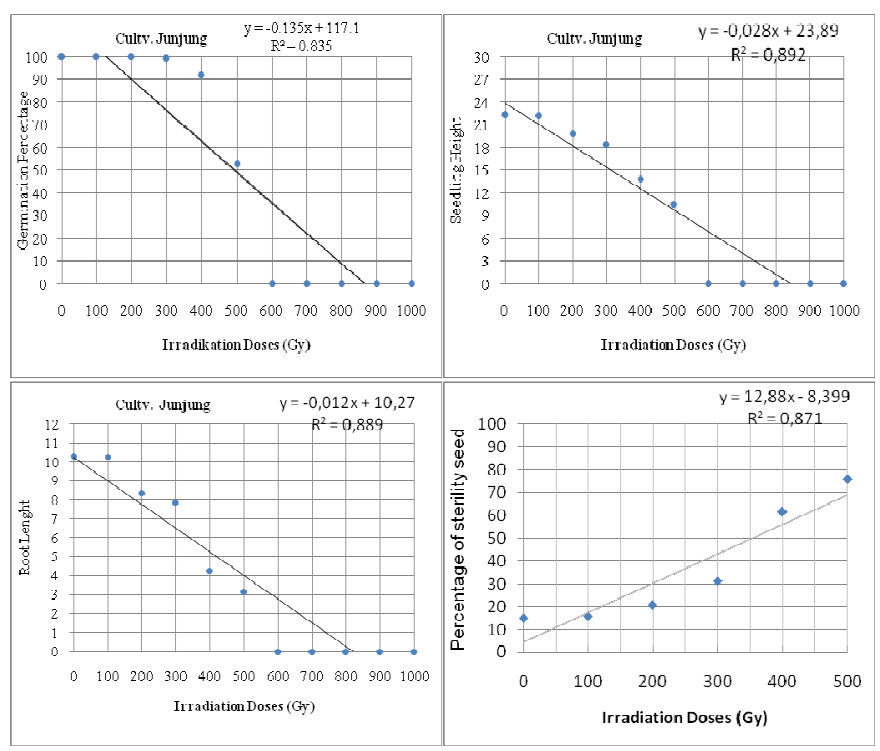

Fig. 1. The response curve gamma irradiation treatment at various doses on germination and seedling growth of cultivars Junjung. (a) the effect of irradiation on germination, (b) the effect of irradiation on seedling height, (c) the effect of irradiation on root growth. (d) the effect of irradiation on sterility seeds.

The germination percentage of observations obtained by the mathematical equation where $y=-0.135 x+117.1$, so the LD50 values obtained at 497.04 Gy irradiation dose. Highlow levels of oxygen and water molecules $\left(\mathrm{H}_{2} \mathrm{O}\right)$ in the irradiated material, will affect the process of ionization of free radicals are formed that affect radiosensivitas plant cell [11]. In addition, the lethal activity of ionizing radiation on cells resulting in the loss of mitotic activity, resulting in a loss of genetic material [1]. This leads to a low rate of germination and seedling growth and can even cause death in plant material (lethal) as shown in Figure 1a, 1b, and 1c.

At the seedling height and root length also seen that the higher the dose of irradiation also affect the growth response. High growth response of seedlings and root length decreased due to the growing size of the irradiation dose. At doses above 500 Gy just a little seed that grows and then death. This is in line with the opinion [17], [4], which explains that the treatment of certain mutagens in serealea has a high correlation with sprouts $\mathbf{M}_{1}, \mathrm{M}_{1}$ germination and mutation frequency.

One thing that is expected in the physiological damage induced mutation is the smallest and genetic damage as much as possible. This is a very valuable factor in generating high genetic variability. In this study the $\mathrm{LD}_{50}$ values obtained are within the range of 400-500 Gy dose, but in a dose range is still causing panicle sterility levels are very high (Figure 1.d.). High doses of radiation will increase sterility in plants panicles $M_{1}$ [7]. From Figure 1d. also can be seen that for a dose of 200-300 Gy panicle sterility levels ranging between $20-30 \%$, while the percentage of sterility dose of 0-100 Gy panicle hardly much different. 
Gamma irradiation at a dose of 200 Gy can cause chlorophyll mutations in $\mathrm{M}_{2}$ population as shown in Table 1 . While the origin of the plant cultivars (control) there is no mutation of chlorophyll. According to [10], the chlorophyll mutation is an indication of genetic damage, which is characterized by the formation of chlorophyll in leaves. It was observed that at a dose of 200 Gy irradiation has produced a number of chlorophyll mutations are quite spacious with 7 different type of mutation, namely Albina, alboviridis, chlorina, virescen, tigrina, marginata, and striata. Some types of mutations that appear on $\mathrm{M}_{2}$ nurseries can be seen in Figure 2.

Frequency of chlorophyll mutants in $\mathrm{M}_{2}$ population can also be seen in Table 1. Of the seven types of chlorophyll mutations are formed, the number of mutations towards albino higher when compared with other types of chlorophyll mutations. Chlorophyll mutation frequency obtained $0.17 \%$ and $1.10 \%$ mutant frequency. It is lower when compared to the results reported by [31] by $7.7 \%$ on the variety Hitomebore [26] of $11.2 \%$ and $6.4 \%$ on the cultivar Kuriak Kusuik and Randah Putiah. Tinggi. Chlorophyll mutations that occur in a population of $\mathrm{M}_{2}$ derived from gamma-ray irradiation at a dose of $200 \mathrm{~Gy}$. a mutagenic effect of gamma irradiation at a dose indicating that the genetic diversity of the population has created $\mathrm{M}_{2}$. [31] and [26] also reported that a dose of $200 \mathrm{~Gy}$ is the irradiation dose that is effective in generating useful genetic diversity in breeding programs.

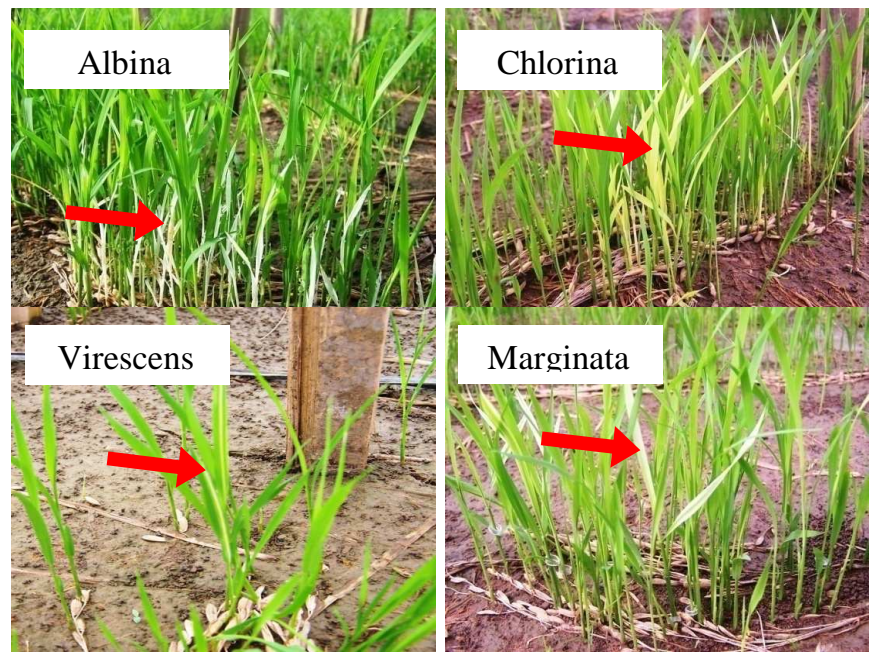

Fig. 2. Movements of chlorophyll which appeared on the M2 generation

At this stage $\mathrm{M}_{2}$ mutant selection activity against the target (early maturity mutant) done. The selection can be done if there is a mutant strain in the population genetic diversity support to do the selection of the target mutant character [10]. Summary genetic parameter data observed through the variable plant height, panicle length, number of productive tillers and flowering dates can be seen in Table 2. In Table 2 it appears that in general it appears that heritability estimates on the overall character including the high category. Only the character of panicle length, which is estimated heritability was moderate, but can be classified nearing high. The high heritability estimates this means genetic factors make important contributions in the next process. Heritability shows how the proportion of a gene can be passed down to the next generation is based on observation of the nature of the observed phenotype [24], [30], as well as the genetic parameters determining the selection of effective systems [25], [30].

TABLE I

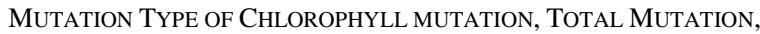
MUTATION FREQUENCY AND FREQUENCY OF MUTANTS IN IRRADIATION DOSE OF $200 \mathrm{GY}$

\begin{tabular}{|c|c|c|c|c|c|c|c|c|c|}
\hline \multirow[b]{2}{*}{$\begin{array}{l}\text { Kult. } \\
\text { Junjung }\end{array}$} & \multicolumn{7}{|c|}{ Chlorophyll Mutation Type } & \multirow{2}{*}{$\begin{array}{l}\text { Frek. } \\
\text { Mutants } \\
(\%)\end{array}$} & \multirow{2}{*}{$\begin{array}{c}\text { Frek } \\
\text { Mutations } \\
(\%)\end{array}$} \\
\hline & Alb & Albo & $\mathrm{Chl}$ & Vir & Tig & Mar & Stri & & \\
\hline Total & 993 & 78 & 567 & 136 & 6 & 193 & 3 & 1.10 & 0.17 \\
\hline $\begin{array}{l}\text { Freq . of } \\
\text { Mutants } \\
(\%)\end{array}$ & 0.55 & 0.04 & 0.32 & 0.08 & 0.00 & 0.11 & 0.00 & - & - \\
\hline
\end{tabular}

Description: The Alb (Albina), Albo (Alboviridis), Chl (Chlorina), Vir (virescens), Tig (Tigrina), Mark (Marginata), Stri (Striata)

TABLE II

GENERAL SUMMARY OF GENETIC PARAMETERS ON THE PART OF THE M2 POPULATION

\begin{tabular}{|l|c|c|c|c|c|c|c|c|c|}
\hline \multicolumn{1}{|c|}{ Character } & $\boldsymbol{\mu}$ & $\mathbf{S d}$ & $\boldsymbol{\sigma}^{2} \mathbf{P}$ & $\boldsymbol{\sigma}^{2} \mathbf{e}$ & $\boldsymbol{\sigma}^{2} \mathbf{G}$ & $\mathbf{h}^{2}$ & Category & $\mathbf{2 . S d}$ & $\begin{array}{l}\text { Varia } \\
\text {-bily }\end{array}$ \\
\hline $\begin{array}{l}\text { Plant Height } \\
(\mathrm{cm})\end{array}$ & $84.76^{*}$ & \pm 4.54 & 21.27 & 9.00 & 12.27 & 0.52 & Tall & 9.09 & Wide \\
\hline $\begin{array}{l}\text { Tassel Height } \\
(\mathrm{cm})\end{array}$ & $26.48^{\mathrm{ns}}$ & \pm 1.69 & 2.90 & 1.46 & 1.44 & 0.46 & Medium & 3.37 & Tight \\
\hline $\begin{array}{l}\text { Numbers of } \\
\text { Productive } \\
\text { tillers }\end{array}$ & $13.63^{\mathrm{ns}}$ & \pm 2.37 & 5.71 & 2.13 & 3.58 & 0.60 & Tall & 4.74 & Tight \\
\hline $\begin{array}{l}\text { Age of } \\
\text { Flowering } \\
\text { (Day) }\end{array}$ & $94.85^{\mathrm{ns}}$ & \pm 2.78 & 10.45 & 1.47 & 9.41 & 0.96 & Tall & 5.55 & Wide \\
\hline
\end{tabular}

Note: :) significantly different at the 0.05 level according to the T test;

${ }^{\mathrm{ns}}$ ) were not significantly different

In addition, the value of variability in plant height and days to flowering is broad while the character panicle length and the number of productive tillers relatively narrow. This means that the induced mutation made more effective in generating high genetic diversity in plant height and days to flowering. But for the panicle length and the number of productive tillers do not have a great influence in generating genetic diversity. The extent of genetic variability in the character of the age of flowering and plant height are the basis for selection against a target mutant character (superior) which is desirable [10], [23], such as early maturing mutants and semi-dwarf. In observation of the middle value of a variable, it is known that the value of the variable character of mutant plants posture is lower when compared with the posture of plant origin. As for the value of the middle third of other variables that are not significantly different from the value of the middle of the plant origin. According to [30], the midpoint of each genotype is associated with idiotipe plants to be achieved and desired as semi-dwarf character and early maturity.

In the generative phase $\mathrm{M}_{2}$ populations do individual selection against a target mutant (mutant early maturing and semi-dwarf). Results of individual selection against mutants early rippening and semi-dwarf can be seen in Table 3 and 
Table 4. In Table 3 shows that the result of individual selection of the candidate mutant very early-maturing group (age 70-80 days flowering) that is as much as 8 plants, and the group of candidates mutant early maturing (flowering age 81-90 days) as many as 78 plants, the mutant frequency of $0.14 \%$. As for the origin of plants (control) contained in the flowering age groups of 91-100 days. Mutant very early maturing and early maturing mutants with semi-dwarf can be seen in Figure 3.

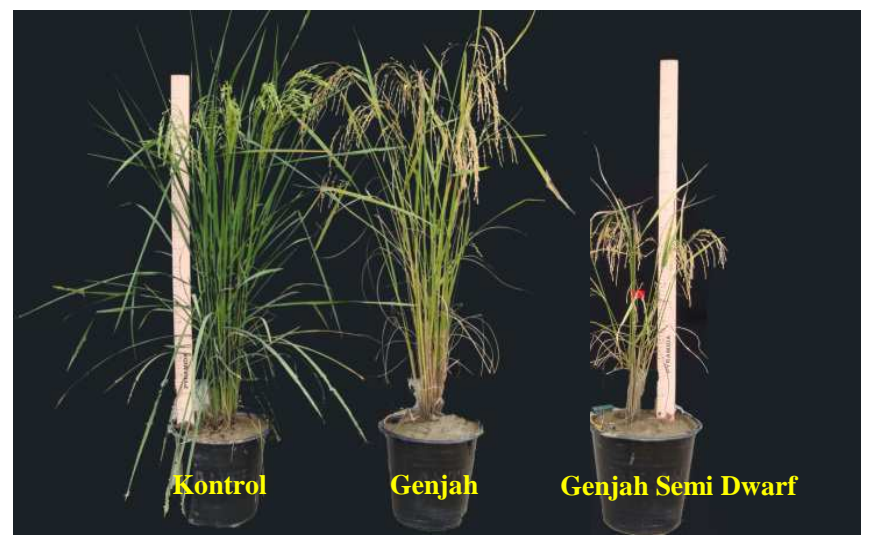

Fig. 3. Mutant very early maturing and early maturing mutants with semidwarf stature genetic improved results through induced mutation were found in $\mathrm{M}_{2}$ population

At doses of gamma irradiation at a dose of 200 Gy can bring out the mutant as a result of genetic changes due to mutations in genes that control the age of the plant. From observations made rapid harvest age can be characterized by more rapid flowering mutant plant age when compared with native plants (plant control). According [12] days to flowering faster highly correlated with crop harvesting age faster. The rapid flowering plants due to genetic changes as a result of mutation induction is done. Treatment irradiation dose of $200 \mathrm{~Gy}$ is the dose that is effective for generating mutants is strategically desirable as mutant semi-dwarf and mutant early maturing [15], mutant grain hairless varieties Cisantana [22], and Mutant early maturing on rice Kuriak Kusuik and High White more low [26], early maturing mutants and semi-dwarf in rice Ase Field and Mandoti [9].

TABLE III

EARLY MATURING MUTANT IN M2 POPULATION DERIVED FROM CULTIVARS JUNJUNG

\begin{tabular}{|c|c|c|c|c|c|c|}
\hline \multirow{2}{*}{ Tread } & \multicolumn{3}{|c|}{ Age for Flowering (day) } & \multirow{2}{*}{$\begin{array}{l}\text { Numbers } \\
\text { of Mutans }\end{array}$} & \multirow{2}{*}{$\begin{array}{c}\text { Numbers of } \\
\text { Populations } \\
\mathrm{M}_{2}\end{array}$} & \multirow{2}{*}{$\begin{array}{c}\text { Frek.Early- } \\
\text { maturing } \\
\text { Mutans } \\
(\%)\end{array}$} \\
\hline & $70-80$ & $81-90$ & $91-100$ & & & \\
\hline $\begin{array}{l}\text { Mutans of } \\
\text { Junjung }\end{array}$ & 8 & 78 & - & 86 & 60.000 & 0.14 \\
\hline $\begin{array}{l}\text { Kult. Junjung } \\
\text { (Control) }\end{array}$ & - & - & TF 50 & - & 6.000 & - \\
\hline
\end{tabular}

Note: TF50 (Time Flowering for Plant Control 50\%)

In addition to producing the mutant-old early maturing, irradiation necessary also produce mutants dwarf and semidwarf. Results of selection of mutant dwarf and semi-dwarf can be seen in Table 4. Generally, in early maturing mutant phenotype candidate has a lower posture (semi-dwarf) when compared with native plants idiotipe. When connected with genetic parameters, in addition to the character of the age of flowering plants, plant height also has a wide genetic diversity values (see table 2 ).

TABLE IV

MUTANT DWARF AND SEMI-DWARF IN $\mathrm{M}_{2}$ POPULATION OF DERIVED FROM CULTIVARS JUNJUNG

\begin{tabular}{|c|c|c|c|c|c|}
\hline \multirow[b]{2}{*}{ Thread } & \multicolumn{2}{|c|}{ Postur of Plant } & \multirow{2}{*}{$\begin{array}{c}\text { Numbers of } \\
\text { Mutans }\end{array}$} & \multirow{2}{*}{$\begin{array}{c}\text { Numbers of } \\
\text { Populations } \\
\mathrm{M}_{2}\end{array}$} & \multirow{2}{*}{$\begin{array}{c}\text { Frek.Early- } \\
\text { rippening } \\
\text { Mutans (\%) }\end{array}$} \\
\hline & Dwarf & $\begin{array}{l}\text { Semi- } \\
\text { Dwarf }\end{array}$ & & & \\
\hline $\begin{array}{l}\text { Mutans of } \\
\text { Junjung }\end{array}$ & 27 & 70 & 97 & 60.000 & 0.16 \\
\hline $\begin{array}{l}\text { Frek. Mutants } \\
(\%)\end{array}$ & 0.05 & 0.12 & & & \\
\hline
\end{tabular}

In Table 4 it is known that the mutant dwarf mutants obtained as many as eight candidates and semi-dwarf mutants obtained as many as 70 candidates mutant with a mutation frequency of $0.16 \%$. This frequency is lower than the frequency of mutant dwarf and semi-dwarf those reported by [3] in the amount of $0.30 \%$ on the cultivar Madhu Malti at a dose of 250-350 Gy irradiation [28], which is $0.26 \%$ in strain $\mathrm{Kl} 237$ with irradiation dose of $200 \mathrm{~Gy}$.

\section{CONCLUSIONS}

Based on the research that has been done can be concluded that the mutation induction is done by gamma ray irradiation can generate genetic diversity is very useful in the selection efforts to obtain the characters age more early maturing crops (early maturing mutant). Orientation doses of LD50 values obtained at $497.04 \mathrm{~Gy}$, but in determining the expected effective dose irradiation doses causing little physical damage as well as a large genetic damage. At a dose of 200 Gy irradiation produced little physical damage as a percentage of germination, seedling height, root length and panicle void percentage when compared with the higher dose of irradiation and generate genetic diversity seen from the emergence of chlorophyll mutation with a mutation frequency of $0.17 \%$. At these doses also has established extensive genetic diversity for the variable character of the age and height of the plant. With the extent of genetic diversity of the resulting mutant candidates that can be selected at this stage of M2. From the selection made at the stage of early maturing mutant M2 candidates obtained as many as 86 candidates with the mutation frequency of $0.14 \%$, as well as dwarf mutant and semi-dwarf mutant were 97 mutants with mutant frequency of $0.16 \%$, Candidates mutant is a mutant candidates hope to have better character as a result to be developed in the future.

\section{REFERENCES}

[1] Ahnstrom, G. 1977. Radiobiology. In Manual on Mutation Breeding. $2^{\text {nd }}$ Ed. IAEA, Vienna. 21-27.

[2] Amano, E. 2004. Practical suggestion for mutation breeding. Forum for Nuclear Cooperation in Asia (FNCA) Mutation Breeding Project.

[3] Bansal, V.K., and P.C. Katoch. 1991. Selection oe semi-dwarf, early maturing and blast resistant mutants after mjutagenic seed treatment in two locally adapted Indian Rice cultivars. Plant Breeding 107 (169)

[4] Conger, B.V., Konzak, C.F. and R.A. Nilan. 1977. Radiation sensitivity and modifying factors. In Manual on AMutation Breeding, $2^{\text {nd }}$ Ed. IAEA, Vienna. 40-42. 
[5] Etti Swasti, I. Suliansyah dan A.A. Syarif. 2007. Eksplorasi, identifikasi dan pemantapan koleksi plasmanutfah padi asal Sumatera Barat. Lembaga Penelitian Universitas Andalas Padang.

[6] Falconer, D.S. and T.F.C. Mackay. 1996. Introduction to Quantitative Genetics. $4^{\text {th }}$ ed. Addison Wesley Longman. Harlow, Essex. UK

[7] Gaul, H. 1977. Mutagen effects in the first generation after seed treatment. In Manual on Mutation Breeding. $2^{\text {nd }}$ Ed. IAEA, Vienna. 40-42

[8] Gustafsson, A. 1938. Studies on the genetic basis of chlorophyll formation and the mechanism of induced mutating. Hereditas, 24: 3393

[9] Haris, A., Abdullah, Bakhtiar, Subaedah, Aminah and K. Jusoff. 2013. Gamma ray radiation mutant rice on local dwarf. Middle-East Journal of Scientific Research 15 (8)

[10] Harten, A.M.van. 1998. Mutation breeding; Theory and practical application. Cambridge University Press.

[11] Herison, C., Rustikawati, Sujono H. S., Syarifah I. A. 2008. Induksi mutasi melalui sinar gamma terhadap benih untuk meningkatkan keragaman populasi dasar jagung (Zea mays L.). Akta Agrosia 11(1):57-62.

[12] Ismachin, M. 1983. Sifat genjah mutan padi varietas Pelita I/1 dan IR5. Disertasi Doktor. Disampaikan pada Fakultas Pascasarjana IPB. Bogor (Tidak Dipublikasikan)

[13] Ismachin, M. 2007. Perkembangan pemuliaan mutasi di Indonesia. Diklat Pemuliaan Mutasi. FPAI BATAN. Jakarta.

[14] Ismachin, M. dan Sobrizal. 2006. A significant contribution of mutation techniques to rice breeding in Indonesia. Plant Mutation Report Vol. 1, No. 18

[15] Juliano, B.O. and C.P. Villareal. 1983. Grain quality evaluation of word rices. IRRI, Los Banos, Manila. Phillippines.

[16] Khan, A.S., M. Imran, M. Ashfaq. 2009. Estimation of genetic variability and correlation for grain yield component in rice (Oryza sativa L.). Am-Euras. J. Agric. Environ. Sci. 6:585-590

[17] Konzak, C.F., R.A. Nilan., J. Wagner., and R.J. Foster. 1965. Efficient chemical mutagenesis Report of FAO/IAEA Technical Meeting. Rome, May 25 - June $1^{\text {st }} 1964.49-70$
[18] Maluszinsky, M., B.S. Ahloowalia, B. Sigurbjornsson. 1995. Application of in vivo and in vitro muitation techniques for crop improvement. Euphytica Vol. 85 (303)

[19] Micke, A., B. Donini, M. Maluszinski. 1990. Induced mutation for crop improvement. Mutation Breeding Review Vol. 7. No. 1.

[20] Mikaelsen, k. 1980. Modifying effects of water content, oxygen and cystein on genetics effects of gamma and fats neutron radiation in barley seeds. In Gamma Field Symposia: 7:1-16

[21] Micke, A., B. Donini, M. Maluszinski. 1990. Induced mutation for crop improvement. Mutation Breeding Review Vol. 7. No. 1.

[22] Mugiono, L. Harsanti, dan A.K. Dewi. 2009. Perbaikan padi varietas Cisantana dengan mutasi induksi. Jurnal Ilmiah Aplikasi Isotop dan Radiasi Vol. 5 (2.)

[23] Roy, D. 2000. Plant Breeding: Analysis and Exploitation of Variation. Narosa Publishing House Calcutta.

[24] Sabu, K.K., M.Z. Abdullah, L.S. Lim, R. Wickneswari. 2009. Analysis of heritability and genetic variability of agronomically important trais in Oryza sativa L. x O. rufipongon Cross. Agronomy Res. 7:97-102.

[25] Susanto, G.W.A. dan M.M. Adie. 2010. Pendugaan heritabilitas hasil dan komponen hasil galur-galur kedelai ditiga lingkungan. Prosiding Simposium PERIPI 5-7 Agustus 2004., Hal: 119-125.

[26] Sobrizal. 2007. Seleksi mutan genjah pada populasi M2 tanaman padi varietas Kuriak Kusuik dan Randah Tinggi Putiah. Jurnal Agrotropika Vol.1 No.

[27] Sobrizal dan Ismachin, M. 2006. Peluang mutasi induksi pada upaya pemecahan hambatan peningkatan produksi padi. Jurnal Ilmiah Aplikasi Isotop dan Radiasi. Vol. 2, No. 1. BATAN. Jakarta.

[28] Sobrizal. 2008. Mutasi induksi untuk mereduksi tinggi tanaman padi galur K1 237. Jurnal Ilmiah Aplikasi Isotop dan Radiasi Vol. 4, No. 2.

[29] Stansfield, W.D. 1983. Theory and Problems of Genetic. $2^{\text {nd }}$ Ed. New York. McGraw-Hill

[30] Syukur, M., S. Sujiprihati., R. Yunianti., dan D.A. Kusumah. Estimation of genetic variance and heritability for yield component characters in chili pepper genotypes. J. Agrivigor10(2): 148-156.

[31] Yamaguchi, H., T. Morishita, K. Degi, A. Tanaka, N. Shikazono, and Y. Hase. 2006. Effect of carbon-ion beams irradiation on mutation induction in rice. Plant Mutation Report. 1:25-27. 